\title{
Digterkongen og strikkestrømpen: To uudgivne breve fra Oehlenschläger
}

Af ordbogsredaktør, cand.mag. Jens Axelsen

Ved et besøg på Islands nationalbibliotek i 1995, hvor islænderen Thorleifur Gudmundsson Repps papirer opbevares, fandt jeg i en uregistreret kasse med materiale, som var skænket til biblioteket af Repps efterkommere i England, et par hidtil ukendte breve fra Oehlenschläger. Det ene er adresseret til „Herr Studiosus Thorleif Gudmundson Repp paa Regentsen“ og lyder som følger [den i teksten forekommende vekslen mellem d og D i „De“, „Dem“ etc. er originalens]:

„den 19 Decbr. 1819

At jeg blev opbragt, kiære Repp, over den Ringeagt som De viste for en heel Stand, som jeg agter, og som jeg endog et Par Aar i mit Ungdomsliv har sluttet mig til, er vist, men jeg seer endnu ikke at jeg dermed har fornærmet Dem. Den blotte

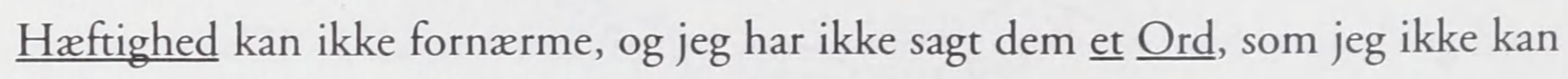

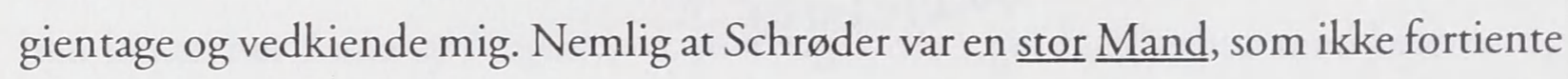
at et ungt Menneske trak paa Næsen af ham. At al Agtelse i Verden var relativ, og at det unge Menneske der endnu ikke har [,havde“ streget over] udmærket sig, og som overseer en siæ1 den Kunstners udmærkede Fortienester med Ringeagt, udsætter sig selv for at bedømmes strængt. - Jeg har sagt at jeg vilde høiagte dem om de i deres Liv bragte det halv saa vidt som Schrøder. Deri er ingen Fornærmelse, thi det var sagt uden al Ironi, og det forhindrer Dem jo ikke i at bringe det videre end ham, hvis De er istand dertil, og mig i at erkiende det, hvis det skulde indtræffe.

Der gives to Maader for en ældre Mand som er kommen til en vis Modenhed at omgaaes haabefulde Ynglinge paa, enten med en vis kold tilbageholdende Forsigtighed - for at undgaae de haarde Kanter der endnu findes hos Ynglingen og maa 
findes, eller paa en varmt venskabelig fortrolig Maade. Men saa maa Ynglingen ogsaa finde sig $i$, at Utaalmodigheden undertiden opluer, naar han selv giver for meget Anledning. - De har undertiden en vis fornem Taushed[,] et \a-a, et Aa ఏo o.s.v. som naar det skal være Svar paa ærlige med Grund fremsatte Meninger har noget sært stødende. Thi skiøndt jeg ikke troer det vilde klæde mig at være fornem, og vise en slags taus Foragt, mod det De med fuldt Hierte og Aabenhed erklærede Dem for, saa maa De dog ogsaa tilstaae at det heller ikke passer sig for Dem imod mig. Det var det som ærgrede mig, da jeg visselig heller ikke den Dag var i godt Lune, og nu blussede jeg op mod Dem men jeg søgte ingen Leilighed til at fornærme Dem! og de havde altsaa hverken i Begyndelsen eller siden Aarsag til at tage det for "Ondskab, " som de i deres brev behager at udtrykke Dem.

Deres øvrige Yttringer vise ogsaa (saavel som min egen Handlemaade mod Dem) at De ingen Grund har til at holde mig for ond. Jeg har viist dem Venskab og sand Deeltagelse, og dersom De nu ikke havde taget mine Ord saa ilde op, men roligt var kommen paa Mandag igien[,] saa havde en venlig Mine og et Haandtryk giort alting godt igien. Nu gik de derimod i Vrede fra Rahbeks i aftes - og skriver mig et Brev til idag, der indeholder langt haardere Udtryk, end jeg i øjebliklig Hæftighed sagde dem. -

Dette vil jeg dog med Fornøielse glemme, da jeg veed Ungdom og Viisdom følges ikke altid ad, om man ogsaa forresten kan være ret god og snild. De har selv fortalt mig, hvordan Prof. Mynster (ved lignende Leiligheder) blev vred - men strax god igien, naar De selv var godhiertig. Hvorfor vil De nu 1 ægge Dem ud med mig for et hæftigt øjeblik[s] Skyld, fra min Side, der blev foranlediget ved en Særhed og Ubillighed fra Deres?

De kan begribe at det ikke er Egennytte eller personlig Fordeel der driver mig til - uagtet den givne Kniv - at ønske Deres Omgang [Venskab streget over]. De er en meget god Sprogmester, men Sprogmestere ere dog ikke saa vanskelige at faae her i Byen; det er min rene Interesse for den unge, flittige kundskabsrige Repp, med Hoved - og uagtet hans overdrevne point d'honneur - gode Hierte, som jeg ikke ønsker at miste.

Vort Forhold til Rahbeks vilde jo ogsaa lide derunder; jeg maatte jo forsvare mig -for Rahbek, og det var jo ogsaa en ubehagelig delicat Sag, da Striden angik hans Smag. 
Jeg haaber altsaa at see Deres Strænghed imorgen som sædvanlig Kl 12, og vil De som jeg, saa er den hele Sag forglemt. Vi ville paa en venlig Maade vogte os for Miserii [?].

Deres

\section{A. Oehlenschläger“.}

Den umiddelbare sammenhæng kan man slutte sig til: Oehlenschläger og Repp har på Bakkehuset haft en diskussion om den berømte tyske skuespiller F.L. Schröder (1744-1816). Oehlenschläger, der selv ville være skuespiller i sin ungdom, har heftigt forsvaret ham mod Repps noget nedladende kritik, hvorover Repp er blevet fornærmet og har sendt Oehlenschläger et brev med en bebrejdelse for ondsindethed. Når Oehlenschläger pointerer at det ikke er af egennytte han ønsker forsoning med ham, og at „Sprogmestere ikke ere saa vanskelige at faae her i Byen" har det at gøre med at Repp på dette tidspunkt underviste Oehlenschläger i latin, som denne fik brug for som professor ved universitetet.

Th.G. Repp (1794-1857) var blevet introduceret til Rahbek, der søgte en lærer $\mathrm{i}$ islandsk, af O.H. Mynster. Mynster var huslæge på Bakkehuset og var Repps lærer på universitetet, hvor han var begyndt at studere medicin. I et brev til Rahbek $\mathrm{d}$. 17. april 1817 karakteriserer Mynster Repp som: „en Islandsk og Medicinsk og Philosophisk Student, som hedder Repp - han er flittig, skikkelig, lærd, skarpsindig og af et godt, maaske noget sært, Hoved - iøvrigt godmodig og temmelig Polyhistor, samt nogle og tyve Aar gammel“. Repp bidrog også til Rahbeks tidskrift Minerva med gendigtninger eller oversættelser af islandske sagaer. „Fra Studerestuen avancerede han til Fruens Cabinet" fortæller P.H. Boye. Repp kom til at høre til blandt Bakkehusets gæster, men med godmodigheden var det nok så som så, og han blev næppe populær. I sine erindringer skriver J. M. Thiele: „Islænderen, Dr. Repp var en sjældnere Fugl og ikke meget omgængelig paa Grund af sit noget hovmodige Væsen, der skaffede ham Navnet „Lord Repp, og under dette Navn taaltes han." Repp optrådte ubehersket over for andre gæster og måtte skrive undskyldningsbreve til Kamma Rahbek. Selv Rahbek undgik ikke at få et uforskammet brev fra ham. En af hans yndlingsaversioner var Oehlenschläger, som han også havde taget parti imod i dennes berømte strid med Baggesen. Han irriteredes over at Oehlenschläger ikke regnede ham for noget, og skriver i et brev fra d. 26 maj 1819 
til Kamma Rahbek: „Jeg vil tilstaa Dem hvad der er sandt at det skulde glæde mig om Prof. Oehlenschl. ikke alene var den største Digter i Dannemark, men jeg saa med stor Grad af Fornøjelse at jeg kunde blive overbevist om at han var den største som der er eller har været paa Jordkloden; større end Kong David, Homer og Eigil Skallagrim; men mon man kunde med Sikkerhed haabe at Oehlenschlæger ret gjerne saa at jeg kun blev en af disse smaa Videnskabsmænd som i sit Fag kunde svare til det som han kalder imellem Digterne de Underordnede Digtere som f. Ek. Herbert i London. Jeg frygter ret meget for, at det rigtige Svar paa dette Spørgsmaal blev nok et ligefremt Nei“. Han skriver videre, at han ved hun gerne så at han nåede den højst mulige „Fuldkommenhed, Udvikling og Dannelse“, men han finder „i denne Henseende i det mindste, ikke saa meget elskværdigt i Professor Oehlenschlæger. Han maaler mig ligesom en Strikkepige en Strømpe, han MAALER mig paa sin uendelige Viisdoms Maalestok. Man siger deri skal jeg finde mig; Ja...siger jeg saa, og finder mig rigtignok i det, men er dog ikke istand til at agte eller elske ham for det." Han skriver at han har fundet det nødvendigt at undskylde sig lidt mod bebrejdelser „som dog vel var noget haarde“ og fortsætter: „Jeg haaber ikke at jeg deri har tilsidesat noget af den Ærefrygt jeg skylder Deres ædelmodige Godhed imod mig ... Deres Straf gaar igjennem mig ... øhlenschl:[s] Straffe slipper jeg med Gudshjelp igjennem, ingenlunde fordi jeg foragter ham men fordi jeg tilstaar det, har for ham en meget ringere Grad af Agtelse end for Dem eller Deres Mand,“ og underskriver sig „Deres og Prof: Rahbeks ærbødigste, hengivneste skjønt ulykkeligvis unge Menneske Repp.“

I et følgebrev til dette fra den næste dag skriver han: „Jeg kan ikke undlade at sige Dem at det smærter mig at tænke paa hvilken Indflydelse Prof. Oehlenschl. vil have paa mit Forhold til Dem i Eftertiden[,] thi paa en Underkastelse under hans Aandelige Magt og Væ1de kan der ikke være at tænke paa for mig; thi det er af den Slags (det maa De tillade) et UNGT MENNESKE ikke har noget Got af; det kalder jeg nemlig Underkastelse at forpligte sig til at glæde sig og finde en contemplativ Nydelse i hvad man anser for ufornuftigt eller falsk; det er sandt: anderledes

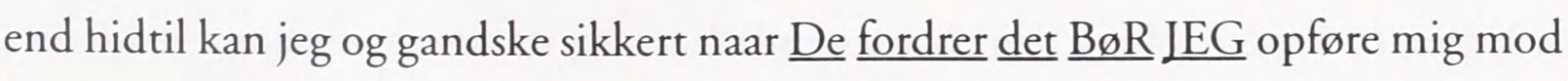
Prof. Oehlenschl. nemlig: jeg skal ikke sige ham imod; det kan og skal og vil jeg - lade være med saasom hans Dogmer ikke angaa mig, skulde han derimod finde en Fornærmelse i at jeg ikke besøger ham skjønt han saa ofte har anmodet mig derom[,] 
saa er det af de Ting jeg ikke kan gjøre for. Jeg har aldrig opført mig (det er jeg vis paa at De i det mindste finder sandt) saaledes mod Oehlenschl. at han kunde derved faa nogen naturlig Lyst til at bede mig besøge; thi al naturlig Interesse er en Smule gjensidig; og for saa vidt det maatte gjelde om Underkastelse saa maatte jeg ganske oprigtig talt meget hellere DRÆBE mig selv. De selv Beste Frue har indset Følgerne af en saadan Underkastelse og de ligge saare klare for mig. - Og jeg maatte dog gjerne vide hvilket andet end just dette Underkastelses Forhold Hr. Prof. Oehlenschl vilde fordrage imellem os[,] ogsaa deri kan jeg holde mig til Deres eget Vidnesbyrd. "Det fremgår ganske tydeligt at hans sympati for Oehlenschläger kan ligge på et meget lille sted, men grunden til denne antipati er dunkel. At forholdet ikke er blevet bedre kan man se af det nyfundne brev. Det vidner om Oehlenschlägers venlige sindelag at han ulejliger sig med at skrive dette brev til Repp, som synes at have været ret utålelig, men måske er det, som det antydes, for Rahbeks skyld.

I sine erindringer fortæller Oehlenschläger hvordan han, med udsigten til i 1820 at skulle skrive universitetsprogrammet og holde den latinske tale ved reformationsfesten, var begyndt at læse latinske forfattere. Men deraf kunne han jo ikke lære at skrive, og da han ikke syntes han kunne være bekendt at lade andre skrive tingene for sig „saa besluttede jeg heller i Guds Navn paa min Gammelalder (jeg var dengang 40 aar) at gaae i Skole igien, at tage en Lærer i Latinen og hos ham skrive min daglige Stiil. Dette gjorde jeg da ogsaa, og Herr R e p p hialp mig et Aarstid meget trolig." De dyrkede også taleøvelser men da Oehlenschläger ikke kunne fordrage at lære grammatik - han havde dog, siger han, både lært sit modersmål og det tyske sprog, som han mente han var ret god til, uden at terpe grammatik - blev det efter naturmetoden, dog efter indlæring af de nødvendigste bøjninger og de vigtigste regler. Han fortæller selvironisk hvordan det gik. Resultatet var, at „det komiske, men naturlige Tilfælde ofte indtraf, at en Sætning, som min Lærer tilstod var ciceroniansk, afvexlede med en fæl Sprogbommert ... Saaledes sad jeg da i et par Aar og øvede mig, først med Herr Repp, siden med min Ven, Overlærer (nu Rektor) Olsen. Med Repp begyndte jeg ogsaa at prate Latin, naar vi gik ud og spadserede sammen til Frederiksberg. Jeg mindes endnu, at jeg standsede engang med ham i Alleen, udenfor Fredriksberg Kirkegaard, i en vanskelig Sætning, og det havde slet ikke været urimeligt, om de Døde over min Phrase havde vendt sig i Gravene“. 
Det andet brev som fandtes mellem de uregistrerede papirer er ret intetsigende, men dog et vidnesbyrd om at Oehlenschläger ikke bar nag.

Repp havde arbejdet med flere ordbogsprojekter, før han til sidst sammen med englænderen J.S. Ferrall udgav en dansk-engelsk ordbog i 1845. Blandt disse projekter må der have været en firesprogs ordbog, for der findes i papirerne flere anbefalinger af en sådan fra forskellige kendte personer, og blandt disse er Oehlenschläger. Udtalelsen lyder:

„At en Ordbog i fire Sprog, som den Herr Boghandler Steen har isinde at udgive, vil være til særdeles Nytte og afhielpe et stort Savn, hvis den Danske bliver ligesaa god som den lignende i Tydskland af Boghandler Brockhaus udgivne, undlader jeg ikke, efter Herr Forlæggerens ønske, at bevidne.

Kiøbenhavn d. 22 febr. 1836

\section{A. Oehlenschläger \\ Professor"}

Den omtalte boghandler levede 1786-1861, hed Chr. Steen og var en kendt og agtet forlægger, bade af litteratur, videnskabelige værker, børnebøger og skolebøger, deriblandt til sprogundervisning.

Henvisninger

Om Repp, se også Jens Axelsen: Leksikografi og Excentricitet, Magasin nr. 4 1995, s. 4ø-55.

Om Ferrall og Repps ordbog, se Jens Axelsen: En rod klassiker, Dansk-Engelsk Ordbog 1845 1995, København 1995.

Om Repp og Bakkehuset kan man 1æse i Breve til og fra Adam Oehlenschläger, 2 RK., BD. V, p. 213-14, med videre henvisninger. Meget af det her fortalte står der, blot er brevene her fyldigere citeret. Endvidere i P.H. Boye:
Om Karen Margrethe Rabbeks Brevvexling og hendes Correspondenter, Kjøbenhavn 1881. Originalen til Repps brev findes i $\mathrm{Ny} \mathrm{kgl}$. Samling 1456, til Mynsters Add. 1040.

Om Repp og Oehlenschläger, se Adam Oehlenschläger: Erindringer, Bd. IV, s. 33-4, og Vilh. Andersen: Adam Oehlenschläger, Manddom og Alderdom, København 1899, p. 152. 